\title{
The Politics of the Labor Movement Revitalization: The Need for a Revitalized Perspective
}

\author{
Lucio Baccaro, Kerstin Hamann and Lowell Turner
}

Unions everywhere are struggling. Globalization, with its supporting neo-liberal ideology, encourages employers and governments to push vigorously against the constraints of employment regulation. Unions have to fight to protect past gains, resist decline and find new allies. To some extent, labor is always on the defensive in a capitalist economy, where ownership and economic decision-making lie largely beyond the reach of workers and unions. Yet the competitive pressures of today's increasingly global capitalism accentuate the pressure. Firms have new options and increasing mobility, far beyond those that most workers and unions can claim.

One response is common to all of our country cases, despite other differences. Unions are everywhere re-launching themselves as 'political subjects', as actors engaged not just in collective bargaining and workplace regulation, but also in the broader aggregation of political and social interests (Pizzorno, 1978). Labor movement politics today go well beyond traditional links with lab our-friendly parties and negotiations with governments, to involve grass-roots politics and local campaigns. The exact forms taken by such political strategies are shaped differently in each country according to the challenges faced, existing institutions and opportunity structures. But in all cases, the shift toward a fuller political subject orientation lies at the center of contemporary strategic adaptation and revitalization'.

\section{The Politics of Revitalization}

In an age of expanded capital mobility, external support becomes essential for union survival, and unions have increasingly acted accordingly. The support they need in a global economy is unlikely to come from their role in the economic sphere alone. In some countries in the past, this role has been justified in terms of value added to production (through increased productivity, contribution to skill development, reduction in transaction costs, and prevention and resolution of conflict) (Freeman and Medoff, 1984; Kochan and Osterman, 1994). Today, it is increasingly difficult to make such a case; consequently, the relationship with employers (those ultimately responsible for the recognition of unions as economic actors) is becoming increasingly tense.

In any event, in most countries, it has always been accepted that unions are not just economic actors. Labor movements aggregate and represent the interests of large numbers of working men and women, and thus play an important role in democratic politics - where each vote is counted equally, independent of economic power. By strengthening their role as political intermediaries, unions seek to obtain the support and influence they need to survive. Even movements without a tradition of 'political unionism' are becoming more proactive political subjects, particularly by reconstituting the union as a key actor in local grass-roots politics. The 
ways in which unions go about developing expanded political strategies also influence, and are closely linked to, their actions in other fields such as organizing, coalition building, internal reform and international solidarity.

While globalization, increased competition and concurrent processes of work reorganization help explain why union revitalization efforts everywhere include expanded efforts to gain external support and alliances, these driving forces cannot account for the different types of political engagement unions have pursued. In this respect, the major difference among our five countries (a difference that appears to account for much of the variation in union strategy) lies in the degree of institutional embeddedness of national labor movements. Unions are institutionally embedded when their organizational fortunes are at least partially uncoupled from their labor market strength, thanks to institutional arrangements such as automatic extension clauses, representation in decision-making bodies, legal frameworks and public funding. Unions whose primary source of strength is in their membership base appear more likely to seek expanded external support by organizing and mobilizing the unorganized. Such organizing drives often differ from the conventional in that the focus is even more on the community than the enterprise. In addition, where traditional institutional channels are blocked such unions often turn to coalition building with various social movements and citizenship groups at the local as well as national level. Thus American and British unions, with a weak institutional position, have promoted organizing and rank-and-file mobilization on a growing scale.

By contrast, unions more entrenched in the socio-political system pay less attention to organizing, since declining membership does not represent the same immediate threat to organizational survival and has less impact, at least in the short run, on union influence on labor market and social policies. Because of their access to national policy-making, such unions focus at that level, often to the detriment of coalition building with other social groups. Thus in Germany, Italy and Spain, unions rely to a large extent on institutional position. In Italy and Spain, indeed, unions were able to capitalize on the failure of unilateral state reform efforts to relaunch their political roles at the national level.

Hence union strategies depend to a significant extent on the institutional resources available, including access to the policy-making sphere. If unions find or build adequate political and institutional supports, they have less incentive to mobilize the membership, organize the unorganized, build coalitions with other groups, or give support to grassroots initiatives. The irony is that a strong institutional position can reduce incentives to organize, which may be essential to sustain long-term influence; while conversely, organizing unions in America and Britain face enormous obstacles and are hard pressed to sustain gains in the absence of adequate institutional supports.

\section{National Experience Summarized}

As argued in the introductory article by Carola Frege and John Kelly, our five focal union movements present remarkable variation in their institutional and organizational characteristics. In spite of these differences, we find that all union movements are increasing their political activism, broadly conceived. As to the precise contours of political mobilization strategies, two profiles emerge. One centers on institutional involvement or social partnership as the major channel for union revitalization: Italy and Germany exemplify this approach. The other, social 
movement unionism, involves grass-roots mobilization through organizing and coalition building, and is epitomized by the recent course taken by much of the American labor movement.

In the 1990s, Italian unions played key roles in the design and implementation of major political and economic reforms, from incomes policies to pensions and labor market reform. Cooperation with government, particularly (but not exclusively) at the national level, was not entirely of the unions' own initiative. The collapse and moral delegitimation of the most important political parties gave the unions an opportunity to ally themselves with weak centerleft governments that were striving to pass controversial reforms. Institutional involvement paid off handsomely, as Italian confederal unions were able to increase their influence considerably in the 1990s. Such a strategy, however, is not open to all union movements: governments and employers have to be willing to grant inclusion - not a foregone conclusion in many cases. In addition, institutional involvement may come at the expense of coalition building and organizational innovation.

In other words, when unions become entrenched in high-level politics, they may fail to invest in their relationship with workers and other social groups and hence undermine their own bases of power and influence in the longer run. In the Italian case, the opening of a rift between the top union leadership and the workers was avoided through organizational reforms that strengthened the links between leaders and members and involved the rank and file in decisionmaking processes. In the 1990s, however, Italian unions did not do much to organize new members among service or contingent workers, nor was coalition building with other social groups a strategic priority.

The American labor movement presents a very different approach to union revitalization. At the core of its strategy is an emphasis on organizing, with a meaning broader than just recruiting new members and replenishing union coffers: it is a way for the unions to regain the moral high ground lost since the 1970 s and to present themselves as more than narrow 'special interest groups'. Organizing drives often target workers in poorly paid and insecure jobs, many of them held by women, minorities and immigrants. Tactics move beyond the National Labor Relations Board (NLRB) framework to include community mobilizations that pressure employers to recognize unions voluntarily To pursue their goals, unions adopt tactics pioneered by the civil rights movement or non-governmental organizations (NGOs), including the 'mobilization of shame', in campaigns that seek to maximize media coverage and provoke a moral backlash among the general public against the exploitation of workers and in favor of union recognition. Coalition building is a major component of this broadly conceived approach to organizing. Unionization becomes part of a broader fight for social justice, in which labor works with human rights, environmental, religious, student, feminist and other community groups in campaigns such as 'living wage' and anti-sweatshop. Such mobilizations, as in the case of Justice for Janitors, often bring in many new members. From an organizational point of view, this strategic reconfiguration has generated efforts to revive horizontal union structures, including central labor councils in many cities.

Strategies pursued by contemporary American unions are the most innovative in our sample, but two points need to be emphasized. First, they are not solely the result of grassroots activism and local experimentation: national unions are key actors. Grass-roots campaigns are generally designed and implemented by professional organizers dispatched by national unions, sometimes against the will of local officials. Second, it is not clear how sustainable these strategic 
innovations are in the long run, unless major political changes occur in the USA. American unions have stepped up activism in politics by investing in the electoral campaigns of pro-labor candidates and by greatly expanding grass-roots voter education and get-out-the-vote campaigns. Results since 1996 have been positive but limited. Labor has so far been able to fight off anti-union and anti-worker measures; but as such measures escalate under the present administration, it is unclear how long unions will be able to hold back the tide. Much will depend on the fruits of expanded political activism.

The other labor movements in our sample are closer to either the American model of grass-roots mobilization or the Italian model of institutional involvement. Their strategic profiles, however, are less clear cut. The experience of the British labor movement has several things in common with the American. British union leaders are well aware that organizing new members is a necessary precondition for union revitalization, and some have borrowed from the organizing tactics of American unions, especially with regard to the use of well-trained, professional organizers. As in the USA, the union headquarters are directly involved in organizing efforts at the local levels.

British unions on the whole, however, appear less steadfast than the most active American unions in the pursuit of organizing. The return of the Labor Party to power has opened up another, more traditional channel of influence, and organizing efforts have expanded only gradually in the past few years. So far, the change of government has not produced remarkable pro-labor changes in the legal framework, while much of the union-constraining legislation passed by previous Conservative governments is still in place. Nevertheless, the Employment Relations Act of 1999 has encouraged union recognition and growth, so that membership decline in the UK has been halted, if not yet reversed.

There is similar ambiguity in the relationships between British unions and other social groups. In the years of Conservative rule, such groups were important allies of the union movement in the fight against privatization and the contracting out of public services. With Labor in power, the development of social alliances was perhaps no longer so high on the union agenda, although this may be changing in current battles around further privatization and the quality of public services. The British union movement is also one of the few for which international strategies play a central role, supporting Britain's full participation in the process of European integration. Notably, the Trades Union Congress (TUC) came out early in support of joining the EMU. British unions seek through European integration some of the institutional resources that they lost in the Thatcher era.

The trajectory of the Spanish unions in the 1990s is in some respects similar to the Italian. As in Italy, the political context has been hospitable to labor inclusion (especially during minority government rule) and the unions have assumed a series of administrative roles that used to be the exclusive prerogative of the state. In particular, the phasing out of the Francoist system of labor ordinances has encouraged union participation in the design of a new regulatory framework for the labor market: one in which collective bargaining plays a bigger role (at least in theory). Union involvement in policy-making has, however, been less extensive than in Italy: no social pact has emerged comparable to those in Italy (and in several other countries) in the 1990 s.

Much of the Spanish union effort has gone in to augmenting the scope of collective bargaining and developing workplace union structures. Results have been mixed. Only a very low 
percentage of the workforce is covered by company agreements; instead, most collective contracts are negotiated at higher levels, especially the regional-sectoral level, and these are extensive enough that about 80 percent of the Spanish workforce is covered. Spanish unions have paid greater attention than the Italian to the need to step up organizing efforts, given low levels of membership in the early 1990s. Most organizing activities center around workplace elections, which take place every four years. As in Italy, the legitimacy of the unions is determined not simply by unionization rates, but more importantly by their generally strong performances in workplace elections.

German unions today appear to be muddling through: no clear strategic reorientation is visible. While this is consistent with traditional incrementalism in German industrial relations, this might indicate that too much institutional embeddedness can stifle innovation. As elsewhere in the world, German unions have experienced membership decline and falling collective bargaining coverage; yet this does not seem to have stimulated the radical innovations that have emerged elsewhere.

Union attention has been directed toward social partnership at company level. In particular, the unions have sought to accommodate employer demands for greater flexibility through controlled decentralization, increasing the bargaining autonomy of the works councils within a framework of general rules. Union participation in policy-making at the national level, in the so-called 'Alliance for Jobs', has produced limited results. One of the reasons for this failure has been labor's unwillingness to relax its commitment to collective bargaining autonomy and allow state interference in the process of wage determination.

Union mergers have been high on the agenda of the German unions, to cut personnel costs and overheads and increase organizational efficiency. We are not persuaded that these measures are anything but defensive. Britain has also seen a wave of union mergers in the past decade. In a country like Britain, with its fragmented union structure, mergers may help to reduce interunion competition and increase coordination - though it is not clear that this has actually occurred. German unions were, however, much less fragmented to begin with. It is too early to say whether mergers in Germany will pave the way toward union revitalization. Much depends on what kind of relationship is established between leaders and workers in the amalgamated unions, especially at ver.di, the newly merged service-sector union (now Germany's largest). If leaders find ways to involve workers more fully in the internal life of the new organizations, and especially in decision-making processes, the result might be increased coordination and greater effectiveness. If not, bureaucracy may intensify and the capacity of unions to represent the changing world of work may decline in Germany as it has in many other countries.

\section{The Literature Reconsidered}

Frege and Kelly have provided a rich and comprehensive framework to explain contrasting cross-national union revitalization strategies. With the evidence now available from our five country studies, we would highlight two of their causal variables: social and economic change and institutions. As we have argued above, the first explains the generalized prominence of political strategies across very different contexts, while the second accounts for contrasting strategic emphases both in politics and in addition to politics across our five countries. More precisely, institutions explain the contrasting influence placed on organizing and coalition building on the 
one hand and social partnership on the other. In addition, the relative weakness of organizational reform and international solidarity efforts can best be explained by the defense of existing organizational and institutional interests, essentially also an institutional variable.

Postwar industrial relations analysis in the USA operated within an America-centered pluralist perspective, assuming a stable social system and well-functioning subsystems such as industrial relations, with a focus on institutions and the details and effects of policies such as collective bargaining (Dunlop, 1958; Kerr et al., 1960; Slichter et al, 1960). The mutual recognition of the two major actors, unions and business, ensured stability of the industrial relations system, and was itself the consequence of a withering away of class conflict across the advanced world and its substitution by the joint search for technical solutions to the problems of industrialism (Dunlop, 1958; Kerr et al., 1960). This perspective, which reflected postwar growth and stability through the mid-1960s, as well as the cold war dominance of the American mass production economy, was challenged from a comparative perspective in the 1970 s and 1980s by a new European literature on corporatism (Berger, 1981; Goldthorpe, 1984; Schmitter and Lehmbruch, 1979). While this broadened the scope of analysis, moving labor and business out of the subsystem and into a more central position in the political economy, the focus remained on institutions and policies. Both perspectives, pluralism and corporatism, were foundations for the 'new institutionalism' of the 1980s and 1990s (Hall, 1986; March and Olsen, 1989; Steinmo et al, 1992).

Meanwhile, the social and economic instability of the 1960 s and early 1970 s inspired a new literature that sought to understand and explain the rise and fall of social movements. The strike waves of the late 1960 s and early 1970 s across western Europe and North America did inspire a more critical industrial relations literature, particularly in western Europe; but particularly in the USA, more attention was devoted to the civil rights, anti-war, women's and environmental movements. While a few studies brought labor and social movements together (Crouch and Pizzorno, 1978; Sabel, 1982), analytical currents moved significantly apart. In the USA at least, and in Europe (notably in Germany), labor was viewed for the most part as an established force with institutional support (and perhaps thus even part of the problem rather than the solution), while social movements were seen as fresh, insurgent, and fighting for space within the political economy and society (Habermas, 1989; Offe, 1985).

Just as American labor largely failed to ride the social movement wave of the $1960 \mathrm{~s}$ (Turner, 2002), so too did the literatures on industrial relations and political economy fail to incorporate the insights of a rich, new, social movement literature. And, with the decline of the social movements of the 1960 s, the field was once again cleared for a narrower focus. This time, however, it was impossible to ignore the increasing effects of global economic pressure as well as the newly aggressive posture on the part of many firms and states. Hence the American literature of the 1980 s recognized that the previously established institutions of industrial relations no longer constituted a stable system; instead, the new perspective emphasized the strategic choice of employers, who increasingly opposed unions and undermined traditional collective bargaining arrangements in their response to increasingly competitive world markets (Kochan et al., 1986; Piore and Sabel, 1984). In the USA, and by extension Britain (where industrial relations as a distinct field of analysis was most firmly rooted), dynamic markets and employer opposition (often backed by government policy) eroded traditional modes of regulation and offered little hope for unions beyond concession bargaining and the acceptance of new employer-led flexibility 
and labor-management cooperation.

While the industrial relations literature of the 1990 s was dominated by strategic choice on the one hand, and institutionalism on the other, a new mobilization perspective emerged hand in hand with the revitalization of labor movements, especially in the USA and UK (Bronfenbrenner et al., 1998; Johnston, 1994; Kelly, 1998; Turner and Hurd, 2001). In contrast to earlier literature, revitalization research emphasized the key role of union strategies, of unions and workers as actors with choices that matter.

Early postwar theorists (industrial relations scholars, political scientists, and sociologists) had seen unions as integrated, stable parties to enduring bargaining arrangements, with rankand-file participation largely unnecessary. Workforce demobilization was an assumption common to theorists of American business unionism and European corporatism alike. Kochan et al. (1986) insisted that unions did have choices, but none were very promising, with options limited by employer attitudes and competitive markets: cooperation and limited participation seemed the best route for some, but offered little hope for turning around the protracted decline of the American labor movement. For the new institutionalism also, union behavior was shaped by institutional and political constraints, and there was little room for labor as a movement, for expanded rank-and-file activism, for activist leadership committed to reform, and for an expansion of democracy in the workplace and beyond.

The latest wave of labor scholarship, by contrast, examines the potential for unions to serve as proactive organizers and system builders, grappling with and shaping the challenges they face, to a large extent through the mobilization of participation. This literature, to which these essays seek to contribute, thus brings together insights and perspectives from the long- neglected (or pigeon-holed) social movement literature with strategic choice from the industrial relations literature, and the new or historical institutionalism from comparative political economy.

We have learned a great deal from strategic choice and institutionalism. We build on concepts such as actor choice, strategic alternatives, transformation, and the powerful shaping influence of existing institutions. But we also believe earlier perspectives are flawed. None of their conceptual frameworks, for example, predicted the American Federation of Labor and Congress of Industrial Organizations (AFL-CIO) and parallel TUC turn toward organizing and local mobilization. Both postwar industrial relations analysis and new institutional perspectives favor system stability, taking institutions and bargaining arrangements as given. Strategic choice with its focus on transformation is more dynamic, reflecting changing world markets and power relations; yet the emphasis is still on shoring up collective bargaining and shifting toward labormanagement cooperation. Our work, by contrast, seeks to integrate institutions, global markets, politics and rank-and-file mobilization into a comprehensive actor-based framework, with a focus on describing and explaining contemporary labor activism, its presence or absence, successes and failures.

\section{The Argument Summarized}

Changing economic conditions (including intensified international capital mobility, trade competition and new work organization) are driving unions into expanded political participation. This is true whether unions are weak or relatively strong, partnership oriented or militant, entrenched in existing institutions or fighting for survival. Unions privilege political action 
because unions need external support to shore up their influence against the dynamic firms of a market economy. The commonality of union political engagement allows us to rule out institutional, historical or cultural variables, including political opportunity structure, as decisive in pointing unions toward politics. Rather, unions everywhere respond to the pressures of global capitalism by recasting themselves and deepening their efforts as political actors, beyond more limited traditional roles as labor market intermediaries.

Unions have always done this to some extent in politically democratic market economies. Unions deepen their roles as political subjects when they go beyond collective bargaining and workplace regulation to engage in the broad aggregation and representation of political and social interests (Pizzorno, 1978). Factors such as institutions and opportunity structures shape the particular ways in which national union movements go about articulating strategies for political, economic and social renaissance. A key difference is between those countries where unions rely on social partnership and those where unions have shifted toward rank-and-file mobilization or social movement unionism. Unions have moved toward organizing where their institutional position is weak, but where their institutional position is stronger or the political opportunity structure more open, unions have focused on building social partnership - although in Italy and in Spain, the consolidation of institutional position has depended on rank-and-file participation (from strike readiness to works council elections).

Unions engage politically in search of external and especially state support. Political power, at least at the outset, is itself based on labor's primary asset: the rank-and-file membership. When unions have used such power to build institutions of inclusion (such as comprehensive collective bargaining and codetermination), they may then rely on social partnership and de-emphasize the mobilization of participation. Where they have a weak institutional position, they are more likely to rediscover the rewards of organizing and rank-andfile mobilization, as well as coalition building in civil society. Where unions successfully establish empowering institutions, democratic participation may narrow into an elite-based, 'corporatist' project, with active member participation fading away (thus raising concerns for the future). Where they have only a weak institutional position, union leaders may have little choice but to encourage or rely on expanded rank-and-file participation. In short, the degree and type of institutional embeddedness help account for the strategies unions adopt ${ }^{\mathrm{ii}}$.

Institutional factors also explain differences in union relationships with political parties and institutions. In this respect, union strategies range from 'concertation' in Italy and Spain (more or less institutionalized involvement in public policy-making) to lobbying and voter mobilization in the USA and Britain. Union involvement in policy-making takes place where governments are weak or where a few unions or confederations are both strong and dominant. Where these conditions do not hold, unions seek to influence the policy-makers rather than participating in policymaking directly. In the USA, union political action has shifted from an emphasis on giving money to candidates to a focus on voter-education drives and get-out-thevote campaigns. This shift, too, was made possible by the ample possibilities for political influence allowed by the decentralized American political system.

The other revitalization strategies considered in this study forganizational reform and international solidarity) have been less visible so far across the five countries. This does not mean they are unimportant; in a global economy, they are essential. Unions in all five countries are arguably weak in both these critical areas, a finding that is deeply troubling. While global 
capitalism pushes unions toward both organizational reform and international solidarity, officeholders and in many cases, members themselves resist, in defense of parochial interests. It is ironic that at a time when there is much debate as to whether the national state still has sufficient capacity to regulate markets in a global economy (Berger and Dore, 1996; Garrett, 1998), unions continue almost single-mindedly to target the national state (and sub-national regional and local governments) for external support. While international solidarity efforts are increasingly important and widespread, they still occupy only a small portion of the overall union agenda.

We also find little evidence anywhere that mergers have contributed to union revitalization or evidence of serious internal organizational reform (in spite of much talk and many meetings and conferences). In this regard, we note the intriguing combination in Italy of social partnership and organizational reforms favoring worker discussion and involvement, and aimed at preventing a degeneration of social partnership into demobilized elite-based corporatism. As in other countries, however, democratic organizational reforms in Italy seem to have lost momentum in recent years.

\section{Policy Implications}

We have seen that unions in all the countries examined have engaged in new forms of political engagement; but that these varied according to contrasting institutions and political opportunity structures. Our analysis points to a possible dilemma facing contemporary labor movements: where unions have strong institutional support, they may not encourage the mobilization necessary to maintain that strength and avoid stagnation or decline. German unions in particular, but also Italian and Spanish, may find their power slipping away unless they overcome inertia and turn more fully to membership activism. When unions in Spain and Italy experienced a weakening of their positions in the 1980s, a stronger membership base might have prevented decline. On the other hand, American and British unions may devote massive resources to organizing yet still find the institutional landscape overwhelmingly against them. If these unions lack the institutional support to sustain organizational innovations, they may be tempted to give up and concentrate on their core competences', that is, servicing their shrinking membership base (as American business unions did for too many postwar decades).

One way of attenuating the effects of this dilemma is to become more globally conscious: that is, not only to link up with foreign unions in solidarity campaigns (a pressing need), but to learn the lessons of union successes and failures in other countries as well. American unions used to believe they were the greatest (and it is a step forward that today they know they are not). Many French and Italian unions in the 1960 s and 1970 s believed they were the authentic militant class strugglers as against their corporatist, collaborationist northern neighbours. As French and Italian unions reeled in the 1980 s, German unions (which had proselytized social partnership and codetermination as the model for the rest of Europe) felt vindicated. In a global era, it is time to move beyond union jingoism: labor everywhere needs to learn and import lessons from abroad.

German, Spanish, and Italian unions can learn from grass-roots innovations developed by their Anglo-Saxon counterparts, and the latter could learn something from the political and institutional strategies of their continental colleagues. Institutional embeddedness, however, is only partially of the unions' own making. The degree to which the lessons of Continental 
European countries are applicable to the USA or even Britain may be more limited than vice versa. While a particular strategy aimed at revitalizing the labor movement might be effective in a given institutional context, a similar strategy may do little for unions in another country with a different set of institutions. To illustrate, where collective bargaining coverage is closely tied to membership levels (as in Britain), it makes sense for unions to concentrate on recruitment drives and organizing. However, where union bargaining rights are tied to the results of workplace elections open to all workers, whether unionized or not, and where collective agreements apply to all workers regardless of union membership (as in Spain or Italy), resources spent on organizing might not be the most efficient way to revitalize unions. Similarly, when unions focus on politics, they may resort to grass-roots voter mobilization where unions are fragmented; where they are more centralized and a few unions or confederations are dominant, national political action might prove more effective.

How successful current political and other strategies will be for unions is a question for future research. Success is difficult to predict, because unions have an interactive relationship with the larger political and economic environment as well as with employers. With limited resources, unions have to make difficult decisions on how best to strengthen their position. In all cases, more than one strategy makes sense - some combination, for example, of local mobilization, political action and coalition building. While each component may be of varied importance across countries, such strategic combinations clearly strengthen labor's overall position, broadening the base from which to operate. Future evaluation of strategic successes and failures will also shed light on the possible convergence of union strategies, in circumstances of growing global union cooperation and mutual learning as well as increasingly similar national economic environments as globalization proceeds.

\section{Ackowledgement}

Our thanks to the Ford Foundation, ILO, Friedrich-Ebert-Stiftung and Cornell University for supporting this research. The views expressed in this article are those of the authors and do not necessarily represent those of the organizations with which they are affiliated.

\section{References}

Berger, S. (ed.) (1981) Organizing Interests in Western Europe. Cambridge: Cambridge University Press.

Berger, S. and Dore, R. (eds) (1996) National Diversity and Globa/ Capitalism. Ithaca: Cornell University Press.

Bronfenbrenner, K., Friedman, S., Hurd, R., Oswald, R. and Seeber, R. (eds) (1998) Organizing to Win: New Research on Union Strategies. Ithaca: ILR Press/Cornell University Press.

Crouch, C. and Pizzorno, A. (eds) (1978) The Resurgence of Class Conflict in Western Europe Since 1969, 2 vols. London: Macmillan. 
Dunlop, J.T. (1958) Industrial Relations Systems. New York: Holt and Company. Freeman, R.B. and Medoff, J.L. (1984) What Do Unions Do? New York: Basic Books.

Garrett, G. (1998) Partisan Politics in the Global Economy. New York: Cambridge University Press.

Goldthorpe, J.H. (ed.) (1984) Order and Conflict in Contemporary Capitalism. Oxford: Oxford University Press.

Habermas, J. (1989) The Structural Transformation of the Public Sphere. Cambridge: MIT Press.

Hall, P. A. (1986) Governing the Economy: The Politics of State Intervention in Britain and France. Oxford: Oxford University Press.

Hall, P. and Soskice, D. (eds) (2001) Varieties of Capitalism: The Institutional Foundations of Comparative Advantage. Oxford: Oxford University Press.

Johnston, P. (1994) Success While Others Fail: Social Movement Unionism and the Public Workplace. Ithaca: ILR Press.

Kelly, J. (1998) Rethinking Industrial Relations: Mobilization, Collectivism and Long Waves. London: Routledge.

Kerr, C, Dunlop, J., Harbison, F. and Myers, C. (1960) Industrialism and Industria/ Man. Cambridge: Harvard University Press.

Kochan, T.A. and Osterman, P. (1994) The Mutual Gains Enterprise. Boston: Harvard Business School Press.

Kochan, T.A., Katz, H.C. and McKersie, R.B. (1986) The Transformation of American Industrial Relations. New York: Basic Books.

March, J. and Olsen, J. (1989) Rediscovering Institutions. New York: Free Press.

Offe, C. (1985) Disorganized Capitalism. Cambridge: MIT University Press. 
Piore, M.J. and Sabel, C.F. (1984) The Second Industrial Divide: Possibilities for Prosperity. New York: Basic Books.

Sabel, C.F. (1982) Work and Politics: The Division of Labor in Industry. Cambridge: Cambridge University Press.

Schmitter, P. and Lehmbruch, G. (eds) (1979) Trends Towards Corporatist Intermediation. Beverly Hills: Sage.

Slichter, S.H., Healy, J.J. and Livernash, E.R. (1960) The Impact of Collective Bargaining on Management. Washington: Brookings Institution.

Steinmo, S., Thelen, K. and Longstreth, F. (eds) (1992) Structuring Politics: Historical Institutionalism in Comparative Analysis. Cambridge: Cambridge University Press.

Turner, L. (2002) fReviving the Labor Movement: A Comparative Perspective', in D. Cornfield and H. McCammon (eds) Labor Revitalization, JAI series on Research in the Sociology of Work, forthcoming.

Turner, L. and Hurd, R. (2001) 'Building Social Movement Unionism: The Transformation of the American Labor Movement', in L. Turner, H. Katz and R. Hurd (eds) Rekindling the Movement: Labor's Quest for 21st Century Relevance, pp. 9-26. Ithaca: ILR Press.

\footnotetext{
' Our analysis is based on the five national cases examined in the preceding articles; but we believe that our arguments will hold up when tested against the experiences of unions in additional advanced industrial societies.

il This thesis is consistent with the distinction between coordinated and liberal market economies (Hall and Soskice, 2001).
} 